Georgia State University

ScholarWorks @ Georgia State University

\title{
Are College-Educated Police Officers Different? A Study of Stops, Searches, and Arrests
}

\author{
Richard Rosenfeld \\ University of Missouri-St. Louis \\ Thaddeus L. Johnson \\ Georgia State University \\ Richard Wright \\ Georgia State University
}

Follow this and additional works at: https://scholarworks.gsu.edu/cj_facpub

Part of the Criminology and Criminal Justice Commons

\section{Recommended Citation}

Rosenfeld, Richard, Thaddeus L. Johnson, and Richard Wright. 2020. Are College-Educated Police Officers Different? A Study of Stops, Searches, and Arrests. Criminal Justice Policy Review, 31: 206-236.

This Article is brought to you for free and open access by the Department of Criminal Justice and Criminology at ScholarWorks @ Georgia State University. It has been accepted for inclusion in CJC Publications by an authorized administrator of ScholarWorks @ Georgia State University. For more information, please contact scholarworks@gsu.edu. 
Running head: ARE COLLEGE-EDUCATED OFFICERS DIFFERENT?

In the wake of controversial and widely publicized incidents involving the use of deadly force by the police against racial and ethnic minorities, President Obama appointed the President's Task Force on 21st Century Policing to examine current law enforcement policies and offer recommendations to improve policing in the United States. A prominent theme running https://scholarworks.gsu.edu/throughout the Task Force's final report is that reforms should be adopted to make policing more just, impartial, unbiased, and sensitive to the needs of diverse communities. As one of the recommendations to achieve this objective, the Task Force recommended that "the Federal Government, as well as state and local agencies, should encourage and incentivize higher education for law enforcement officers" (President's Task Force on 21st Century Policing, 2015: recommendation 5.11). Toward this end, the Task Force called for innovative recruitment approaches to develop "a more highly educated workforce with the character traits and social skills that enable effective policing and positive community relationships" (p. 51). ${ }^{1}$

The President's Task Force on 21st Century Policing was not the first Presidential panel to advocate higher education as a means of improving the quality and effectiveness of policing. The President's Commission on Law Enforcement and the Administration of Justice (1967), appointed by President Lyndon B. Johnson in 1965, was tasked with recommending strategies for addressing rising crime rates amid a period of civil unrest in cities across the United States. Among the 1967 Commission's many recommendations was that educational standards for those charged with enforcing the law should be raised, with a strong emphasis on recruiting more college-educated officers. Underpinning this recommendation was the optimistic assumption that a college education would make police officers more sensitive and responsive to the distinctive needs and challenges of the communities they serve (Fogelson, 1977). There was little empirical 


\section{ARE COLLEGE-EDUCATED OFFICERS DIFFERENT?}

support for this assumption (Carter, Sapp, \& Stevens, 1989). However, it was anchored in a longstanding call for better educated police officers that predate the Johnson Commission recommendation by more than fifty years, stretching back to August Vollmer (Brunson \& Wright, 2016; Oliver, 2017). That undoubtedly added to its political credibility.

In response to the 1967 Commission's report, Congress established the Law Enforcement Assistance Administration (LEAA). Through LEAA's Law Enforcement Education Program (LEEP), the Federal government authorized loans and scholarships to encourage police officers to pursue higher education. Although LEEP's funding only lasted a few years, these financial incentives, coupled with an unprecedented expansion in higher education, clearly had the desired effect. In 1960, only three percent of police officers held a bachelor's degree. By 1974, just seven years after the publication of the Commission's report, that figure had grown to nine percent (National Planning Association, 1978). The percentage of college-degreed officers rose steadily over the next several decades, standing at just under a quarter in 1990 (Carter \& Sapp, 1990) and approximately a third in 2010 (Reaves, 2015). The boom in the number police officers with a college education, however, appears to be driven mostly by the upward trend in educational attainment in the general population, rather than agency policy (Baro \& Burlingame, 1999; Hawley III, 1998).

Despite substantial and sustained growth in the number of police officers with a college degree, little is known about the way they do their jobs, especially in their day-to-day interactions with community residents. Does having a college degree make police officers more tolerant, understanding, and fair, as the President's Taskforce on 21st Century Policing intended (see, also, Hawley III, 1998)? Does it intensify their professional aspirations and commitment to agency-based criteria for advancement, which may have little to do with or even be at odds with 


\section{ARE COLLEGE-EDUCATED OFFICERS DIFFERENT?}

the ongoing effort to improve police-citizen relations? Does the effect of college education on police decision making differ by officer sex and race?

Amidst a new round of protests resulting from police killings of unarmed black men in cities across the United States, the answers to such questions take on added urgency. They also remain unclear. It is an opportune time to take stock of and advance research on whether, and if so how, higher education shapes contacts between police and the citizens they are obliged to serve (Brunson \& Wright, 2016).

This paper examines the relationship between higher education and police officer decisions during traffic stops. We focus on traffic stops because they represent the most common point of contact between citizens and police (Eith \& Durose, 2011), providing us with an ideal opportunity to explore the influence of higher education on real world police decision making. Improving police-community relations and enhancing police legitimacy are the key objectives of the President's Task Force on 21st Century Policing. The decisions that officers make during traffic stops play an important part in shaping public perceptions of police legitimacy (Allen \& Monk-Turner, 2010; Gibson, Walker, Jennings, \& Mitchell-Miller, 2010; Ren, Cao, Lovrich, \& Gaffney, 2005).

We begin by reviewing the literature on higher education and policing, focusing on what is known and remaining uncertainties about the link between a college education and police officer attitudes, aspirations, and behavior. Next, we describe the sample and outline our methodology. We then present our findings. Finally, we explore the policy implications of our research. 


\section{ARE COLLEGE-EDUCATED OFFICERS DIFFERENT?}

\section{Background}

Prior research on higher education in policing has focused on the relationship between higher education and police officers' attitudes, aspirations, and behavior on the job. As shown below, that research has produced decidedly mixed results.

\section{College Education and Police Attitudes}

What role does a college education play in shaping police officers' occupational attitudes? The answer to this question continues to be the subject of debate. Some researchers have found no significant attitudinal differences between officers with and without a college education (Johnson, 2012; Sherwood, 2000; Worden, 1990). Others have noted positive attitudinal characteristics associated with college attendance, including lower levels of cynicism, fewer punitive beliefs, and greater commitment to ethical behavior (Carlan \& Byxbe, 2000; Osborne, 2014; Telep, 2011).

Still other researchers, however, have reported that college-educated officers are significantly more likely to hold unfavorable attitudes toward the importance of impartiality and maintaining positive police-community relations. Paoline, Myers, and Worden (2000), for example, studied the relationship between education and occupational attitudes in a sample of 638 patrol officers in two municipalities. After controlling for officers' race, gender, years of experience, and other factors the researchers found that, compared to officers with just a high school diploma, those who attended college were more supportive of selective enforcement and expressed less favorable views of citizens and community oriented policing.

In another study, Paoline, Terrill, and Rossler (2015) investigated the link between higher education and occupational attitudes among more than 2,100 officers representing eight police departments. They concluded that, net of statistical controls including gender, race, years of 


\section{ARE COLLEGE-EDUCATED OFFICERS DIFFERENT?}

experience, and military background, patrol officers with a baccalaureate degree or higher were significantly more frustrated with work and cynical of administration than their less educated peers.

\section{College Education and Aspirations for Promotion}

Researchers have long recognized that a desire for professional advancement often underpins police officers' pursuit of a college degree (Buckley, McGinnis, \& Petrunik, 1993). It is surprising, therefore, that little research has been conducted on the relationship between higher education and promotional aspirations (Albarano, 2015). Evidence from the few studies that have been done suggests that better educated officers have stronger promotional aspirations than those without college experience (Gau, Terrill, \& Paoline, 2013; Hayeslip, 1989). Their pursuit of promotion, driven by ambitiousness and self-confidence in policing abilities, often corresponds with a proactive enforcement style, resulting in a more energetic brand of policing (Bozza, 1973;

Gau et al., 2013; Glasgow, Green, \& Knowles, 1973; Kakar, 1998, 2003). When collegeeducated officers are unable to realize their ambitions, they are likely to become dissatisfied with the job, manifesting itself in harsh or unfair treatment of citizens (Ercikti, Vito, Walsh, \& Higgins, 2011).

If the research on the impact of higher education on officers' promotional aspirations is limited, even less is known about the effect of promotional aspirations on policing behaviors. What is clear, however, is that ambition for promotion plays a key role in shaping police officers' enforcement orientation (Gau et al., 2013). In other words, police officers know what it takes to get promoted and behave accordingly.

Some scholars have pointed out that a college education is only a preferred qualification for promotion, not a requirement (Baro \& Burlingame, 1999; Carter et al., 1989) and that 


\section{ARE COLLEGE-EDUCATED OFFICERS DIFFERENT?}

conventional measures of productivity like traffic stops, searches, and arrests carry greater weight in such decisions (Paoline, 2001). College-educated officers may be more ambitious than their less well-educated colleagues, leading them to be especially committed to conventional promotion criteria and zealous in enforcing the law (Gau et al., 2013; Johnson, 2011). Consistent with this hypothesis, Paoline and Terrill (2005) found that better-educated officers tended to embrace aggressive enforcement strategies and to operate with a higher degree of selectivity, distrust of citizens, and resentment toward supervision.

\section{College Education and Police Behavior}

Several studies have examined the relationship between higher education and indicators of job performance, including citizen satisfaction (Cascio, 1977; Kappeler, Sapp, \& Carter, 1992), officer misconduct (Fyfe \& Kane, 2005; Lersch \& Kunzman, 2001; Manis, Archbold, \& Hassell, 2008), and use of force (Paoline \& Terrill, 2007; Sherman \& Blumberg, 1981; Terrill \& Mastrofski, 2002). Only a few researchers, however, have explored the association between higher education and the traditional police performance measures most relevant to the current study -- traffic stops, searches, and arrests (Alpert, MacDonald, \& Dunham, 2005; Paoline \& Terrill, 2005; Rojek, Rosenfeld, \& Decker, 2012; Rydberg \& Terrill, 2010).

Traffic stops and searches have garnered a considerable amount of empirical attention from researchers. Most of these studies have examined either the appropriateness of these enforcement practices or the role of citizen demographics in police decision making (Schafer, Carter, \& Katz-Bannister, 2004). A few studies have explored the influence of officer characteristics on stop or search decisions (Alpert et al., 2005; Close \& Mason, 2006; Decker \& Rojek, 2002; Rojek et al., 2012; Rydberg \& Terrill, 2010; Paoline \& Terrill, 2005; Smith \& Klein, 1983). 


\section{ARE COLLEGE-EDUCATED OFFICERS DIFFERENT?}

To our knowledge, just one published study focuses on the impact of college education on traffic stops. In this inquiry, Alpert and colleagues (2005) sought to determine whether college experience played a part in the formulation of suspicion that precedes officers' decision to conduct a stop. An examination of 174 police-citizen incidents in Savannah, Georgia, produced no evidence of a relationship between level of education and officers' stop behaviors. Among a small number of studies to explore the influence of education on police search behavior, Rydberg and Terrill (2010) used observational and qualitative data to assess the impact of college attendance on officers' decision to perform a vehicle search. Based on a sample of 3,356 officer-motorist encounters in Indianapolis, Indiana, and St. Petersburg, Florida, they found that educational attainment did not have a significant effect on search behavior. Rojek et al. (2012) included college education as a control variable in a study of the interactive effects of officer and driver race on searches conducted during traffic stops. In contrast to the study by Rydberg and Terrill (2010), Rojek et al. (2012) concluded from an analysis of the administrative records of nearly 70,000 police-driver interactions that better-educated officers were more likely to initiate a vehicle search during traffic stops.

Compared to stop or search decisions, the impact of education on officer arrest behaviors has received somewhat more attention from researchers, yielding contradictory results. In an early investigation of the arrest patterns of 24 officers in the Southwest, Glasgow, Green, and Knowles (1973) found that officers with college degrees made arrests at higher rates than their less educated colleagues. Using the same data, Bozza (1973) concluded that younger, college educated officers were significantly more likely to arrest than their peers. By contrast, Finckenauer's (1975) vignette study indicated that higher education mitigated the propensity to arrest in a sample of 98 police recruits undergoing basic training in New Jersey. 


\section{ARE COLLEGE-EDUCATED OFFICERS DIFFERENT?}

In research based on data from the Police Services Study, Smith and Klein (1983) initially found that, at the individual level, a college education was not significantly associated with an officer's arrest behavior. But subsequent analyses indicated that the effect of education on the frequency of arrests depended on the proportion of college-educated personnel within a department. Fewer arrests occurred in departments with high levels of educational attainment than in those with lower levels of formal schooling. More recently, Rydberg and Terrill (2010) explored the relationship between higher education and the decision to arrest. Based on a sample of 322 officers, a multivariate analysis revealed that attending college did not significantly influence arrest behavior.

\section{Gender and Race Differences}

The effect of college education on police decision making in traffic stops may differ by officer gender and race. Female and minority officers have been subject to prejudice and discriminatory practices in American police departments. Limited prior research suggests that a hostile or non-supportive workplace could strengthen or weaken the ambitions and aspirations of female and minority officers with a college degree.

The President's Commission on Law Enforcement and the Administration of Justice (1967) had little to say about gender differences in police attitudes, aspirations, or behavior. That is not particularly surprising given the very small proportion of female police officers and prevailing attitudes about the presence of women in male dominated professions at the time. More surprising is the absence of sustained consideration of the contributions of female police officers, and the professional challenges they face, in the President's Task Force on 21st Century Policing (2015). The lack of attention to women in policing is ironic given that some of the very skills and behaviors needed to improve police-community relations -- empathy, communication, 


\section{ARE COLLEGE-EDUCATED OFFICERS DIFFERENT?}

tolerance -- are characteristics commonly attributed to women. These stereotypical attributions receive some support in empirical research (e.g., Eagly \& Johnson, 1990; Olson, Rosso, Demers, Divatia, \& Killgore, 2016; Rueckert \& Naybar, 2008).

Prior research has shown that, similar to college-educated officers, female police officers report lower levels of job satisfaction than their male coworkers (Hassell \& Brandl, 2009). Female officers also report a work environment hostile to women (Seklecki \& Paynich, 2007). As noted earlier, job dissatisfaction can manifest in harsh or unfair treatment of citizens (Ercikti et al., 2011).

Given their minority status, female police officers also must confront perceptions that they are "tokens" in a male dominated and "masculinized" work environment. Research has shown that tokens may experience several adverse outcomes, including performance pressures and stress emanating from heightened visibility, social isolation, and restricted opportunities for advancement (Stroshine \& Brandl, 2011; Yoder, Aniakudo, \& Berendsen, 1996). Some women respond by employing methods to "fade into the background" (Martin, 1979). Women who possess a high achievement orientation, however, tend to increase their work output and seize opportunities to promote their efforts (Derks, Van Laar, \& Ellemers, 2016). Achievement oriented female officers tend to overcome tokenism and expected gender role conformity through the adoption of masculine professional norms and behaviors (Archbold \& Schulz, 2008). Some scholars have described these ambitious female officers as careerists who proactively engage in policing, arrests, and competition with male officers to attain promotions or more prestigious assignments (Archbold \& Schulz, 2008; Shelley, Morabito, \& Tobin-Gurley, 2011). We might expect, therefore, college-educated female police officers to be particularly achievement oriented and ambitious in their enforcement decisions in traffic stops. 


\section{ARE COLLEGE-EDUCATED OFFICERS DIFFERENT?}

Whereas the President's Commission (1967) said little about the recruitment of women, it did call for hiring more racial minorities. The Commission, however, did not address the question of how working in a profession historically dominated by white males might shape minority officers' perceptions and performance. Many commentators believe that a diverse department promotes cultural tolerance and encourages citizen support of police (Hassell \& Brandl, 2009). Although diversifying the force has remained a common theme in police reform efforts (Brown \& Frank, 2006), law enforcement continues to struggle with allegations of racial discrimination, especially concerning employment and promotion practices (Roberg \& Kuykendall, 1997). Minority officers regularly encounter barriers and other race-related hardships at work (Hassell \& Brandl, 2009; Stroshine \& Brandl, 2011). Prior research suggests that an officer's race may override the influence of gender or education on personal judgments about limited access to prized assignments, biased performance evaluations, and other perceived unfair practices (Archbold \& Schulz, 2012; Gustafson, 2008; Stroshine \& Brandl, 2011).

How such views might affect black officers' enforcement behavior is unclear. On the one hand, we might expect ambitious college-educated black officers, like ambitious female officers, to respond to a hostile work environment through determined adherence to traditional reward and promotion criteria. College-educated black officers, therefore, should engage in discretionary stops, searches, and arrests at higher rates than their non-college peers. On the other hand, there is evidence that a hostile and discriminatory workplace promotes cynicism among black officers that may dampen their professional ambition. Perceptions of constant scrutiny and lack of support and recognition from higher-ups rob minority officers of incentives to actively engage in police work (Stroshine \& Brandl, 2011). Disengagement reduces productivity, which then leads to poor evaluations and disciplinary disparities (Rojek \& Decker, 


\section{ARE COLLEGE-EDUCATED OFFICERS DIFFERENT?}

2009; Texeira, 2002). Cynicism and disengagement may be especially prevalent among collegeeducated black officers, who believed their credentials would result in better treatment. On balance, then, we leave open the question of whether college-educated black police officers differ from non-college black officers in their enforcement behavior during traffic stops.

\section{Current Study}

The literature on higher education and policing does not offer a clear or consistent picture of how college-educated police officers differ from those without college with respect to their attitudes regarding their department and the community in which they work or their decision making and behavior on the job. Somewhat more consistent findings suggest that collegeeducated officers are more achievement oriented than other officers. There is little convincing evidence that college-educated officers are better equipped to handle the challenges of contemporary policing, as the President's Task Force on 21st Century Policing (2015) portrayed them. Some evidence suggests, however, that these officers' stronger achievement aspirations may make them more zealous in enforcing the law according to conventional criteria for advancement.

We follow up on the latter indications from prior research in the current study. We hypothesize that college-educated police officers are more achievement oriented than less educated officers and, as such, are more attentive to departmental promotion standards and procedures. In most U.S. police departments, promotion continues to be based on evidence of vigorous enforcement activity, including stops, searches, and arrests (Paoline, 2001). We compare police officers with and without a baccalaureate degree with respect to five enforcement indicators based on data on over 60,000 traffic stops in St. Louis, Missouri: stops for non-moving violations, stops for non-speeding violations, discretionary searches of drivers or vehicles, 


\section{ARE COLLEGE-EDUCATED OFFICERS DIFFERENT?}

contraband discovered in searches, and arrests. Throughout, we refer to officers with a baccalaureate degree or higher as "college educated" and those without a baccalaureate degree as "non-college" officers.

We follow prior research and common parlance by measuring college education as having earned a four-year college degree. We recognize, however, that police officers we have termed "non-college" may have attended college, including those who have earned a two-year associate's degree, and may share the hypothesized characteristics and orientations of those who have earned a baccalaureate degree. For this reason, we conduct a supplementary analysis comparing the enforcement decisions of officers who have attended college but do not have a four-year degree with those who have not attended college as well as those who have received a baccalaureate degree.

We expect that college-educated officers are more likely than other officers to stop motorists for engaging in non-moving violations, such as a broken taillight or obstructed windshield, and for less serious moving violations, such as failure to signal when changing lanes. These indicators have been used in prior research as measures of "pretextual" traffic stops -discretionary stops for minor offenses in order to discover evidence of more serious crime (Gumbhir, 2007; Harris, 1997, 1999). College-educated officers may be more eager than other officers to engage in discretionary stops as pretexts to discover serious crimes or simply to demonstrate energetic enforcement activity.

The same logic applies to searches. Some searches are mandatory, such as following an arrest or when an officer observes contraband in plain view (Fallik \& Novak, 2012; Schafer, Carter, Katz-Bannister, \& Wells, 2006). Others are discretionary and require the driver's consent. We expect that achievement oriented college-educated officers are more likely than 


\section{ARE COLLEGE-EDUCATED OFFICERS DIFFERENT?}

others to perform these non-mandatory searches of drivers or their vehicles. The decision to conduct a consent search is based on the officer's assumption that the search will uncover contraband. It is therefore important to determine whether consent searches by college-educated officers are more likely than those by non-college officers to discover contraband.

We also expect that traffic stops by college-educated officers are more likely to result in an arrest than those by less educated officers. In principle, an arrest requires probable cause that a suspect has violated the law. Other things equal, therefore, college-educated officers should be no more likely than others to encounter individuals or circumstances that necessitate an arrest. In practice, arrests remain the time-honored metric of success in law enforcement (White, 2008). For that reason, officers who are especially achievement oriented and desirous of advancement should be more likely than other officers to end a traffic stop with an arrest in circumstances that permit some degree of discretion.

We acknowledge that nearly all police decisions are based on discretion; if they were not, they would hardly qualify as "decisions". We assume, however, that on average the decision to stop a motorist for a non-moving violation permits greater officer discretion than stopping a motorist for a moving violation; stops for a non-speeding violation are more discretionary than stops for a speeding violation; consent searches are more discretionary than searches that accompany an arrest or visible contraband; and some arrests are more discretionary than others. For example, stopping a motorist who is driving 30 miles over the speed limit is far less “discretionary" than stopping someone whose license plate is partially obscured. ${ }^{2}$ We also assume that stopping a motorist for moving violations such as failure to signal or driving too close to another vehicle is generally more discretionary than stopping a driver who is speeding (see Petrocelli, Piquero, \& Smith, 2003; see Schafer et al., 2004). We hypothesize further that, 


\section{ARE COLLEGE-EDUCATED OFFICERS DIFFERENT?}

when there is more room for discretion, college-educated officers will choose the course of action that conforms more closely to conventional departmental review and promotion standards.

Prior research suggests that ambitious and achievement oriented women may respond to tokenism by outperforming their male coworkers to obtain status and promotion in male dominated occupations, including law enforcement (Archbold \& Schulz, 2008; Derks, Van Laar, \& Ellemers, 2016; Martin, 1979). We hypothesize that college-educated female police officers are especially desirous of professional advancement and, therefore, may be even more likely than college-educated male officers to engage in the kinds of discretionary enforcement activity that can lead to promotion. The terms "sex" and "gender" are used synonymously in this study.

College-educated black officers may be subject to competing pressures that promote both more and less vigorous adherence to conventional criteria for advancement. Like their female counterparts, they may respond to hostility and unfairness in the workplace by outperforming other officers. Conversely, the gap between their educational credentials and treatment at work may produce cynicism and disengagement, especially given their negative views of punitive enforcement (Pelfrey, 2004; Sun, 2003). Studies of racial differences in police behavior have produced inconsistent results, with most demonstrating that officer race only negligibly affects performance (Alpert et al., 2005; Close \& Mason, 2006; National Research Council, 2004; Tillyer, Klahm IV, \& Engel, 2012; Worden, 1989). It is difficult to draw firm conclusions from prior research about the complex interplay between officer educational status and race. We therefore do not have specific hypotheses about whether college-educated black officers are more or less likely than other black officers or college-educated white officers to engage in the kinds of discretionary enforcement that are rewarded in most American police departments. 


\section{ARE COLLEGE-EDUCATED OFFICERS DIFFERENT?}

Hispanic officers and those of other races made up approximately 3\% of the SLMPD who conducted traffic stops in 2013 (27 officers), too few for extended analysis.

Throughout this discussion, we have assumed that college-educated police officers are more "ambitious" and "achievement oriented" than other officers. That assumption is based on relatively consistent prior research findings. But the research literature does not reveal whether a college education produces or strengthens police officers' achievement aspirations, or whether achievement oriented individuals are more likely than others to pursue higher education. We have no way of knowing the causal direction of the relationship between higher education and achievement orientation from the data compiled for this study. But, for our purposes, it may not matter.

The current study was motivated by the evident conviction of the President's Task Force on 21st Century Policing (2015) that college-educated officers would be better prepared to address the challenges of policing in a rapidly changing and increasingly diverse society. The Task Force did not recommend more discretionary stops and searches of citizens, and higher arrest rates, as effective ways of responding to the challenges of modern policing. Nor did the President's Commission on Law Enforcement and the Administration of Justice (1967). Yet, based on prior research, those are the outcomes we might expect from adding more collegeeducated officers to the nation's police departments -- regardless of whether they result from higher education itself or pre-existing differences between college-educated and non-college officers.

\section{Data and Methods}

The data for the current study consist of 63,451 traffic stops recorded by officers of the St. Louis Metropolitan Police Department (SLMPD) during 2013. The stop data are based on 


\section{ARE COLLEGE-EDUCATED OFFICERS DIFFERENT?}

SLMPD administrative records and represent all but a small fraction of traffic stops made by SLMPD officers in $2013 .{ }^{3}$ The data include multiple characteristics of the officer who made the stop, the driver, and the stop itself. The officer characteristic of primary interest is whether he or she received a baccalaureate degree or higher. The minimum education requirement for SLMPD officers is high school graduation or an equivalency certificate. The 63,451 traffic stops were made by 842 officers, approximately two thirds of the 1,276 SLMPD sworn personnel in 2013 (St. Louis Metropolitan Police Department, 2014). Just under 30\% of the 842 officers who made at least one traffic stop in 2013 had attained a baccalaureate degree, as shown in Table 1. The date the degree was earned was not provided in the data available for this study. Table 1 also reveals that $85.5 \%$ of the officers who made traffic stops in 2013 were male, $72.8 \%$ were between the ages of 30 and 49, 34.0\% were black, and $71 \%$ were district patrol officers. The demographic makeup of officers who made traffic stops is very close to all SLMPD sworn personnel. According to the SLMPD, in 2013 84.3\% of SLMPD officers were male, $64.5 \%$ were white, $33.0 \%$ were black, and $2.5 \%$ were of other races. The average age of SLMPD officers was 40.5 (St. Louis Metropolitan Police Department, 2014).

The 842 officers averaged 75.4 traffic stops each, although there is a large variance in the number of stops made by the officers ( $S D=147.8)$. Not surprisingly, traffic officers made far more vehicle stops than did officers assigned to district patrol, citywide specialized anticrime units, administrative posts or other duty. Traffic officers made up just 3.7\% of the officers who made traffic stops, but they accounted for nearly a quarter of the stops made in 2013, as shown in the bottom panel of Table 1. Finally, about seven of every ten drivers stopped by SLMPD officers in 2013 were male, just under half were below the age of 30, and 71.0\% were black. ${ }^{4}$ Just over half of the drivers stopped were city residents, about half of the stops were made during 


\section{ARE COLLEGE-EDUCATED OFFICERS DIFFERENT?}

the daytime (6:00AM - 5:59PM), and the remainder occurred during the evening (6:00PM 11:59PM), or night (12:00AM - 5:59AM). These characteristics of traffic stops, officers, and motorists have been used in prior research on police behavior (e.g., Rojek et al., 2012; Schafer et al., 2004, 2006; Smith, Novak, Frank, \& Lowenkamp, 2005).

\section{Table 1 about here}

The five enforcement outcomes under consideration include stops for non-moving violations, stops for non-speeding violations, consent searches (driver or vehicle or both), contraband found, and arrests (see Appendix Table A for detailed descriptions). The focal independent variable is a categorical measure of whether the officer has a baccalaureate degree ( $1=$ college educated, $0=$ non-college $)$. Some research has measured officer educational attainment on an interval scale of years of schooling completed as well as whether the officer has a college degree (see Truxillo, Bennett, \& Collins, 1998). In a supplementary analysis we investigate whether officers who attended college but did not receive a four-year degree made enforcement decisions similar to those of officers who completed college. In our main analyses, however, we follow the lead of most prior research and the recommendations of the Presidential commissions on policing and base our assessment of discretionary enforcement in traffic stops on whether or not the police officer had attained a four-year college degree.

\section{Analytical Strategy}

Our analysis begins with bivariate comparisons of the demographic attributes and duty assignment of college-educated and non-college SLMPD officers. We then compare both groups of officers with respect to the demographic characteristics of the drivers stopped in 2013 . The purpose of the latter analysis is to determine whether college-educated officers differ from others in their exposure to (or selection of) drivers who vary in attributes that may be associated with 


\section{ARE COLLEGE-EDUCATED OFFICERS DIFFERENT?}

the enforcement outcomes of interest. We then proceed to multivariate analyses of the five enforcement outcomes. The outcomes are in binary form $(1,0)$ and are estimated in mixed-effects (random intercept) logistic regression models that adjust the estimates for the clustering of traffic stops within officers. Diagnostic tests on the regression models showed no indication of multicollinearity among predictors (avg. VIF=1.53; max. VIF=3.19).

To determine whether college-educated female officers differ from their non-college counterparts in discretionary behavior, we include an interaction term (male x college) that estimates whether the effect of college education on the enforcement outcomes is conditioned by officer gender. We include a similar interaction term (black x college) to investigate whether the influence of a college education on enforcement outcomes is conditioned by officer race. The results of three models are presented. The first contains no interaction terms. The gender and race interaction terms are included separately in the second and third models. All analyses were conducted with Stata 15.1.

\section{Results}

Table 2 compares college-educated and non-college SLMPD officers with respect to their sex, age, race-ethnicity, and duty assignment. College-educated and non-college officers are also compared with respect to the average number of traffic stops they conducted in 2013 and the sex, age, and race-ethnicity of the drivers they stopped. College-educated officers did not differ significantly from other officers by sex or age. Black officers, however, were significantly less likely than white or other ethnic (other race or Hispanic) officers to have received a four-year college degree. Traffic officers were also less likely to have a college degree than district patrol officers, housing officers, officers assigned to citywide anti-crime units, or those who performed 


\section{ARE COLLEGE-EDUCATED OFFICERS DIFFERENT?}

other duties. Each of these attributes of SLMPD officers is included in the multivariate analyses of enforcement outcomes presented below.

Table 2 about here

As shown in Table 3, college-educated officers averaged about 20 fewer traffic stops in 2013 than did officers without a baccalaureate degree, although the difference is not quite statistically significant at the $95 \%$ confidence level $(p=.066)$. We observe no significant differences in the demographic attributes of drivers stopped by college-educated and non-college officers. This result suggests that college-educated officers did not select for traffic stops drivers with particular demographic characteristics, at least any more than other officers might have. How the demographic characteristics of drivers influenced officer behavior after the stop was made remains to be determined from the multivariate analyses.

Table 3 about here

\section{Multivariate Models}

Table 4 presents the results of mixed effects logistic regressions regarding so-called pretextual traffic stops by SLMPD officers. We do not know whether an officer in fact conducted a traffic stop as a pretext to discover a more serious crime. But, as discussed above, it is reasonable to assume that not all traffic stops are made with the same degree of discretion on the officer's part. We expect, therefore, that college-educated officers are more likely than other officers to stop drivers for non-moving and non-speeding violations.

Those expectations are supported in the SLMPD data. As shown in Table 4, collegeeducated officers were about $20 \%$ more likely than other officers to stop a motorist for a nonmoving violation compared with a moving violation, and they were about $50 \%$ more likely to stop a motorist for a non-speeding violation $\left(\mathrm{OR}=1.200\right.$ and 1.503 , respectively).$^{5}$ In both cases, 


\section{ARE COLLEGE-EDUCATED OFFICERS DIFFERENT?}

college-educated male officers were less likely than their female counterparts to stop motorists for discretionary reasons, but these differences are not statistically significant. Nor do we find that college-educated black officers differed significantly from other officers in discretionary stops. The results withstand controls for several other variables with a significant effect on discretionary traffic stops. Discretionary stops were more likely among officers under the age of 50, when the driver is black or a city resident, and when the stop was made during the evening hours (6:00PM - 11:59PM) rather than other times of the day. Discretionary stops were less likely to be made by traffic enforcement officers and those assigned to anti-crime units and for drivers under the age of 30. Interestingly, black officers were significantly less likely than others to stop motorists for a non-moving violation but more likely to conduct a stop for a non-speeding violation.

\section{Table 4 about here}

When a traffic stop is made, the officer sometimes encounters circumstances that compel a search of the vehicle, driver, or both (Schafer et al., 2006). Such mandatory searches include those resulting from an arrest, drug odor, contraband in plain view, or when the officer is concerned for her or his safety (Schafer et al., 2004). Other searches, however, are more discretionary and require the driver's consent (Higgins, Vito, \& Walsh, 2008). In 2013, SLMPD officers conducted 7,560 searches of drivers or their vehicles. Just over a third (35.3\%) were conducted with the driver's consent. Most of the remainder were searches conducted incident to an arrest, in response to drug odor or other indication of illegal drug possession, or for other reasons that would compel a search. We expect that college-educated officers were more likely than other officers to perform a search based on the driver's consent compared with other reasons. 


\section{ARE COLLEGE-EDUCATED OFFICERS DIFFERENT?}

In results not shown, we found no significant difference between college-educated and non-college SLMPD officers in the likelihood a search was conducted during a traffic stop, when the analysis is based on all searches, regardless of reason or circumstance. ${ }^{6}$ Table 5 presents the results for consent searches by SLMPD officers and whether the search led to the discovery of contraband. We see in the first column of results that college-educated officers were no more likely than other officers to conduct a search of the driver or vehicle with the driver's consent. But that result changes when we include the interaction between college education and the gender of the officer (male $=1$, female $=0$ ), as shown in the second column of the table. Now we observe both a statistically significant main effect of college education on consent searches and a significant interaction effect of officer education and gender. The main effect is positive and the interaction effect is negative, meaning that college-educated male officers are $68 \%$ less likely than their female peers to conduct a search with the driver's consent $(\mathrm{OR}=.320)$. In fact, among male officers, having a college degree had no appreciable effect on consent searches, whereas college-educated female officers were more than twice as likely as non-college female officers to perform a consent search.

These results are graphed in Figure 1, which displays the predicted likelihood of a consent search for male and female officers by educational attainment, with all other variables set to their mean values. It appears that college-educated female officers either requested more consent searches from the drivers they stopped or were more successful than other officers in obtaining compliance with their requests. College-educated black officers, however, did not differ from non-college black officers in the likelihood they conducted a consent search.

Table 5 about here

Figure 1 about here 


\section{ARE COLLEGE-EDUCATED OFFICERS DIFFERENT?}

Contraband, almost always illegal drugs, was discovered in $13.7 \%$ of the searches conducted by SLMPD officers in 2013. Only 3.3\% of the consent searches, however, yielded contraband. As shown in Table 5, college-educated officers were no more likely than other officers to discover contraband in searches to which the driver consented. Few attributes of officers, drivers, or traffic stops are related to the discovery of contraband in these searches. Exceptions are the driver's gender and race. Compared with other searches, officers were significantly more likely to conduct a consent search of male drivers than female drivers, and contraband was less likely to be discovered in consent searches of male than female drivers or their vehicles. Contraband was also less likely to be found in consent searches of black drivers or their vehicles than in those of other drivers; consent searches were relatively less frequent among black drivers as well.

An arrest resulted in 3,522 or 5.6\% of the traffic stops SLMPD officers made in 2013. We found no significant difference between college-educated and other officers in the likelihood they made an arrest, when the analysis is based on all arrests, regardless of the cause or circumstance (results not shown). Most of the arrests (62.0\%) were of individuals wanted on an outstanding warrant, and many of the remainder resulted from a search. When these less discretionary arrests are omitted from the data we find that traffic stops by college-educated officers were twice as likely as those by other officers to result in an arrest $(\mathrm{OR}=2.007$; see Table 6). In fact, educational attainment is the only attribute of officers that is significantly associated with arrest. An arrest was also more likely when the driver was male and when the traffic stop took place during the evening. Contrary to expectations, college-educated female officers were no more likely than similarly educated male officers to end a traffic stop with an 


\section{ARE COLLEGE-EDUCATED OFFICERS DIFFERENT?}

arrest. Nor did college-educated black officers differ significantly from black officers without a college education in arrests.

\section{Table 6 about here}

\section{College Completion or Attendance?}

Throughout our analysis, we have compared the enforcement actions during traffic stops of SLMPD officers who did and did not attain at least a baccalaureate degree. The latter category includes officers who completed some college, and may have earned an associate's degree, but did not obtain a four-year degree. It is possible that the results reported above simply reflect the association between the enforcement outcomes and attending college or earning an associate's degree -- and therefore the role of the cognitive abilities, personality traits, and other factors correlated with admission to and attending college -- rather than a relationship between enforcement actions and college completion.

To find out whether it is college completion that matters with respect to the more discretionary forms of enforcement examined in the current study, we re-estimated each of the models presented in Tables 4-6 with a dichotomous indicator included for officers who attended college but did not earn a bachelor's degree. We estimated these models both with the college completion variable included and omitted. In neither case is the indicator for attending but not completing college significantly associated with the five enforcement outcomes (results not shown). These results suggest that the differences in police behavior during traffic stops we have observed are in fact associated with attaining at least a baccalaureate degree. Whether that is because college completion itself influences enforcement actions or because those officers who completed college differ in other ways not measured here from those who did not finish college remains to be determined in future research. 


\section{ARE COLLEGE-EDUCATED OFFICERS DIFFERENT?}

\section{Discussion}

Two Presidential commissions, a half century apart, have called for more college graduates to join the nation's police departments. The Task Force on $21^{\text {st }}$ Century Policing (2015), in particular, suggested that in order to better address the challenges of policing in ethnically and socioeconomically diverse urban areas where police-community relations are problematic, departments should commit to increasing the number of college-educated officers. The proportion of police officers with a college degree has increased greatly since the 1960s; it remains an open question whether police-community relations, or police services in general, have changed as a result.

The recommendations for more college-educated officers were not backed by systematic empirical evidence showing a relationship between higher education and the "community aware" policing the commissions had in mind. The research literature is decidedly mixed on that score. But prior research does offer some indication of how college-educated police officers differ from those without a college education. They appear to be more achievement oriented and more attentive to performance criteria for professional advancement. Stops, searches, and arrests remain among the most important enforcement metrics for determining who gets rewarded and promoted in U.S. police departments. The primary objective of the current study of a large urban police department was to determine whether stops, searches, and arrests were pursued more stringently by college-educated officers than by officers with less education. Two secondary objectives guided our research. One was to discover whether college-educated female officers were even more achievement oriented and promotion minded than female officers without a college degree or their college-educated male peers. The other was to determine whether workplace discrimination heightened or blunted the ambitions of college-educated black officers, 


\section{ARE COLLEGE-EDUCATED OFFICERS DIFFERENT?}

leading them to be either more productive or less productive than black officers with less education.

We reasoned that, if college-educated officers were more professionally ambitious than other officers, they would be more likely to stop, search, and arrest a motorist for actions that, while technically unlawful, were generally less serious than those more likely to compel a specific police response. We expected that, holding constant other officer, motorist, and event characteristics, college-educated officers would be more likely than others to stop a motorist for a non-moving or non-speeding violation, to request the driver's consent to conduct a search, and to make an arrest when the driver was not wanted on an outstanding warrant and absent evidence from a search. We recognize that the distinction between these "discretionary" enforcement actions and mandatory actions dictated by departmental policy or procedure is not ironclad. Some non-speeding violations (running a red light, for example) are arguably just as or more serious than exceeding the speed limit. In general, however, it seems reasonable to assume that officers have more options when deciding to stop someone for a non-moving violation than for a moving violation or for a non-speeding violation than for a speeding violation. A consent search is optional by definition, both on the officer's and the driver's part. Arrests require probable cause of law breaking, but there is less room for judgment when the suspect is wanted on an outstanding warrant or when a search turns up contraband.

We evaluated our hypotheses with data on more than 60,000 traffic stops in St. Louis. In regression analyses controlling for multiple attributes of officers, drivers, and the stops, we found that college-educated officers were significantly more likely than other officers to stop, search, and arrest motorists under circumstances that, on average, may have allowed for some other or no action. College-educated officers conducted relatively more consent searches that did other 


\section{ARE COLLEGE-EDUCATED OFFICERS DIFFERENT?}

officers, but they were no more likely to discover contraband in searches of the driver or motor vehicle. Whatever talents, skills, or qualities of judgment may distinguish college-educated SLMPD officers from other officers, they evidently do not boost the success rate of their searches.

We found that college-educated female officers were more likely than their male counterparts to conduct a consent search but did not differ significantly from other officers with respect to the other enforcement outcomes under consideration. Finally, we found no significant differences between black officers with and without a college education in discretionary stops, consent searches, or arrests. The impact of a college education on these enforcement outcomes, in other words, appears to be limited to white officers and those of other races.

We conducted ancillary analyses to determine whether our findings could be attributed to officers merely having attended college or earning a two-year degree rather than having attained a four-year degree. We found no significant effects on the enforcement outcomes of attending college without earning a baccalaureate degree. It appears, then, that college completion is responsible for the behavioral differences that distinguish college-educated police officers from those who never went to college or did not obtain a bachelor's degree.

Our conclusions of course are limited to the administrative data available for the current study. For some reason, the results could be specific to the SLMPD or to a single year, a possible threat to the external validity of the study. A more likely threat to the study's internal validity is that other characteristics of SLMPD officers, for which college completion is simply a proxy indicator, explain the association between higher education and enforcement. Many police officers, for example, have past military experience, which could be related to the differences in enforcement found in this study and to police officers' educational attainment. Military service is 


\section{ARE COLLEGE-EDUCATED OFFICERS DIFFERENT?}

not included in the SLMPD administrative data used here. Replications of the current study will be necessary to determine whether the results are generalizable to other cities and police agencies, especially to those with administrative data on traffic stops not available in the SLMPD data.

In line with the results of prior research, we have assumed that college-educated police officers are more achievement oriented and eager for professional advancement than their less educated peers. As such, when circumstances permit a relatively flexible approach to suspected law violation, they are more likely to opt for a "by the book" response. Their decisions to stop, search, and arrest when other officers would proceed differently under the same circumstances could result from professional ambition, but they might also be related to other pre-existing differences between officers who have and have not completed college. College-educated officers may simply be more conservative or risk averse than less educated officers, and more likely to follow rules to the letter. They are no better than other officers at discovering contraband, however, which would seem to rule out the possibility that they have superior "police smarts." Finally, it is possible that something about higher education itself makes police officers either more achievement oriented or scrupulous in adhering to bureaucratic procedure. Whatever learning or social experience that may be, it takes at least four years of higher education to acquire.

A major task for future research, in addition to replicating the study in other cities, is to empirically identify the selection or causal factors linking higher education to differences in police behavior. Another important research objective is to determine why, in contrast to white officers, college-educated black officers do not differ from other black officers in their enforcement behavior. Comparatively few black officers in the current study had a college 


\section{ARE COLLEGE-EDUCATED OFFICERS DIFFERENT?}

degree. It is possible that in police departments with a greater percentage of college-educated black officers, especially in command positions, those officers would have greater confidence in their prospects for promotion and make enforcement decisions more similar to those of their white counterparts. It will also be important to carry out similar studies in cities with populations that differ from St. Louis in race-ethnic composition and police agencies that have larger proportions of Asian officers and those of other races, as well as of Hispanic officers, who may be of any race.

In the meantime, the results of the current study advise against promoting higher education as a way to improve police-community relations, especially in communities where concerns about over-policing are widespread. Simply hiring more college educated officers is not likely to make the police more effective, or more open, understanding, and flexible in their encounters with community members. We do not oppose efforts to recruit more college-educated men and women into policing. Far from it. The results of the current study, in fact, offer some hope for the future of police-community relations, not because college-educated officers are inherently more community-minded than their less-educated counterparts, but rather because they adhere more closely to departmental policies and procedures in the hope of furthering their careers.

The reform oriented police manager whose priority is improving community relations might be well advised to capitalize on the greater ambition of college-degreed officers, using it as a vehicle through which to implement change. If departmental reward and promotion structures are altered to prioritize problem solving, community engagement, procedural justice, and the related changes recommended by the President's Task Force on 21 st Century Policing (2015), our findings suggest that college-educated officers can be a valuable resource to ensure 


\section{ARE COLLEGE-EDUCATED OFFICERS DIFFERENT?}

that the new policies are carried out in practice. The challenge, then, is to change the reward structure of policing. If the results of our study hold in other settings, college-educated officers can be expected to lead the way in adapting to the new set of policy priorities.

\section{Appendix}

Table A. Description of Enforcement Outcomes ${ }^{\mathrm{a}}$

1. Non-moving violation (1), Moving violation (0)

Non-moving violation $(\mathrm{n}=33,147)$

Equipment $(\mathrm{n}=8,578)^{\mathrm{b}}$

License $(n=17,215)^{\mathrm{b}}$

Investigative $(\mathrm{n}=10,848)^{\mathrm{b}}$

Moving violation $(n=30,304)$

Speed $(n=10,922)^{b}$

Lane $(\mathrm{n}=1,971)^{\mathrm{b}}$

Tail $(\mathrm{n}=81)^{\mathrm{b}}$

Signal $(2,184)^{\mathrm{b}}$

Other $(\mathrm{n}=16,077)^{\mathrm{b}}$

2. Non-speeding violation (1), Speeding violation (0)

Non-speed $(\mathrm{n}=52,529)$

Speed $(\mathrm{n}=10,922)$

3. Consent search (1), Other reason (0)

Consent search $(n=2,670)$

Other reason $(n=4,890)$

Drug $(n=1,292)$

Plain view $(\mathrm{n}=198)$

Officer safety $(\mathrm{n}=878)$

Arrest $(n=1,651)$

Other $(\mathrm{n}=871)$

4. Contraband found (1), Contraband not found (0)

Contraband found $(\mathrm{n}=1,039)$

Contraband not found $(\mathrm{n}=6,521)$

5. Arrest (1), No arrest (0) ${ }^{\mathrm{c}}$

Arrest $(n=140)$

No arrest $(n=54,739)$

${ }^{\text {a }}$ Reason recorded by the officer for the traffic stop

${ }^{\mathrm{b}}$ Sum exceeds total because multiple violations recorded

for some stops

${ }^{c}$ Arrests of drivers wanted on warrant or accompanying a search omitted 


\section{Notes}

1. In light of the Trump Administration's reversal of Obama-era police reform initiatives (Charles, 2017; Ingraham, 2017), and law enforcement's recent shift toward lower education standards amid a nationwide police shortage (The Economist, 2017), it is unclear whether the 2015 Task Force recommendations remain a priority for the current Justice Department.

2. A reviewer suggests that college-educated officers might be more likely than non-college officers to stop a motorist for less serious speeding violations. We acknowledge the point, but more detailed data on the speeding violations, such as miles over the speed limit, were not available for this study.

3. SLMPD officers are required to record each traffic stop they make. The data exclude 4,817 traffic stops conducted under a state program requiring stops of commercial trucks for inspection.

4. Blacks made up $45.7 \%$ of the St. Louis population age 16 and over in 2010. St. Louis is an independent city separate from St. Louis County, population 998,954, where blacks constituted $23.3 \%$ of the population in 2010 (U. S. Bureau of the Census, 2010).

5. $\mathrm{OR}=$ odds ratio. The odds ratio is the ratio of the odds of an event or outcome occurring in one category of a variable to the odds of the event or outcome occurring in another category of the variable (Rudas, 1998). We use the shorthand that the outcome is XX\% more or less "likely" to occur in the category shown in the results than in the contrast category not shown.

6. All results not shown are available from the authors on request.

\section{References}

Albarano, R. F. (2015). College education and officer performance: Do college educated police officers perform better than those without a college education? International Journal of Education and Social Science, 2(7), 41-48.

Allen, J., \& Monk-Turner, E. (2010). Citizen perceptions of the legitimacy of traffic stops. Journal of Criminal Justice, 38(4), 589-594.

Alpert, G. P., MacDonald, J. M., \& Dunham, R. G. (2005). Police suspicion and discretionary decision making during citizen stops. Criminology, 43(2), 407-434.

Archbold, C. A., \& Schulz, D. M. (2008). Making rank: The lingering effects of tokenism on female police officers' promotion aspirations. Police Quarterly, 11(1), 50-73.

Archbold, C. A., \& Schulz, D. M. (2012). Research on women in policing: A look at the past, present, and future. Sociology Compass, 6(9), 694-706. 
Baro, A. L., \& Burlingame, D. (1999). Law enforcement and higher education: Is there an impasse? Journal of Criminal Justice Education, 10(1), 57-73.

Bozza, C. M. (1973). Motivations guiding policemen in the arrest process. Journal of Police Science and Administration, 1(4), 468-476.

Brown, R. A., \& Frank, J. (2006). Race and officer decision making: Examining differences in arrest outcomes between black and white officers. Justice Quarterly, 23(1), 96-126.

Brunson, R. K., \& Wright, R. (2016). Straight outta Compton: The rise of criminal justice education and the policing of urban communities. The Criminologist, 41, 3-4.

Buckley, L. B., McGinnis, J. H., \& Petrunik, M. G. (1993). Police perceptions of education as an entitlement to promotion: An equity theory perspective. American Journal of Police, 12(2), 77-100.

Carlan, P. E., \& Byxbe, F. R. (2000). The promise of humanistic policing: Is higher education living up to societal expectation? American Journal of Criminal Justice, 24(2), 235-246.

Carter, D. L., \& Sapp, A. D. (1990). The evolution of higher education in law enforcement: Preliminary findings from a national study. Journal of Criminal Justice Education, 1(1), 59-85.

Carter, D. L., Sapp, A. D., \& Stephens, D. W. (1989). The state of police education: Policy direction for the 21st century. Washington, DC: Police Executive Research Forum.

Cascio, W. F. (1977). Formal education and police officer performance. Journal of Police Science \& Administration, 5(1), 89-96.

Charles, J. B. (2017). Justice Department ends era of pushing police reform. Governing, (September 28). Retrieved from http://www.governing.com/topics/public-justicesafety/lc-sessions-justice-police-reforms-trump-doj-milwaukee.html

Close, B. R., \& Mason, P. L. (2006). After the traffic stops: Officer characteristics and enforcement actions. The BE Journal of Economic Analysis \& Policy, 6(1), 1-43.

Decker, S. H., \& Rojek, J. (2002). Saint Louis Metropolitan Police Department traffic stop patterns. St. Louis, MO: University of Missouri Press.

Derks, B., Van Laar, C., \& Ellemers, N. (2016). The queen bee phenomenon: Why women leaders distance themselves from junior women. The Leadership Quarterly, 27(3), 456469.

Eagly, A. H., \& Johnson, B. T. (1990). Gender and leadership style: A meta-analysis. Psychological Bulletin, 108(2), 233-256. 


\section{ARE COLLEGE-EDUCATED OFFICERS DIFFERENT?}

Eith, C., \& Durose, M. R. (2011). Special report: Contacts between police and the public in 2008. Washington, DC: Bureau of Justice Statistics.

Ercikti, S., Vito, G. F., Walsh, W. F., \& Higgins, G. E. (2011). Major determinants of job satisfaction among police managers. Southwest Journal of Criminal Justice, 8(1), 97-111.

Fallik, S. W., \& Novak, K. J. (2012). The decision to search: Is race or ethnicity important? Journal of Contemporary Criminal Justice, 28(2), 146-165.

Finckenauer, J. O. (1975). Higher education and police discretion. Journal of Police Science and Administration, 3(4), 450-457.

Fogelson, R. M. (1977). Big-City police. Cambridge, MA: Harvard University Press.

Fyfe, J. J., \& Kane, R. J. (2005). Bad cops: A study of career-ending misconduct among New York City police officers. Final Report. Washington, DC: National Institute of Justice.

Gau, J. M., Terrill, W., \& Paoline, E. A. (2013). Looking up: Explaining police promotional aspirations. Criminal Justice and Behavior, 40(3), 247-269.

Gibson, C. L., Walker, S., Jennings, W. G., \& Mitchell-Miller, J. (2010). The impact of traffic stops on calling the police for help. Criminal Justice Policy Review, 21(2), 139-159.

Glasgow, G., Green, R., \& Knowles, L. (1973). Arrest performance among patrolmen in relation to job satisfaction and personal variables. Police Chief, 60(4), 28-34.

Gumbhir, V. K. (2007). But is it racial profiling? Policing, pretext stops, and the color of suspicion. New York: LFB Scholarly Publishing.

Gustafson, J. L. (2008). Tokenism in policing: An empirical test of Kanter's hypothesis. Journal of Criminal Justice, 36(1), 1-10.

Harris, D. A. (1997). "Driving while black" and all other traffic offenses: The Supreme Court and pretextual traffic stops. Journal of Criminal Law \& Criminology, 87(2), 544-582.

Harris, D. A. (1999). Driving while black: Racial profiling on our nation's highways. New York: American Civil Liberties Union.

Hassell, K. D., \& Brandl, S. G. (2009). An examination of the workplace experiences of police patrol officers: The role of race, sex, and sexual orientation. Police Quarterly, 12(4), 408430.

Hawley III, T. J. (1998). The collegiate shield: Was the movement purely academic? Police Quarterly, 1(3), 35-59. 


\section{ARE COLLEGE-EDUCATED OFFICERS DIFFERENT?}

Hayeslip, D. W. (1989). Higher education and police performance revisited: The evidence examined through meta-analysis. American Journal of Police, 8(2), 49-62.

Higgins, G. E., Vito, G. F., \& Walsh, W. F. (2008). Searches: An understudied area of racial profiling. Journal of Ethnicity in Criminal Justice, 6(1), 23-39.

Ingraham, C. (2017). In Trump's 'ruthless' vow, experts see a return to the days of the drug war. The Washington Post (February 10). Retrieved from https://www.washingtonpost.com/news/wonk/wp/2017/02/10/in-trumps-ruthless-vowexperts-see-a-return-to-the-days-of-the-drug-war/.

Johnson, R. R. (2011). Officer attitudes and management influences on police work productivity. American Journal of Criminal Justice, 36(4), 293-306.

Johnson, R. R. (2012). Police officer job satisfaction: A multidimensional analysis. Police Quarterly, 15(2), 157-176.

Kakar, S. (1998). Self-evaluations of police performance: An analysis of the relationship between police officers' education level and job performance. Policing: An International Journal of Police Strategies \& Management, 21(4), 632-647.

Kakar, S. (2003). Race and police officers' perceptions of their job performance: An analysis of the relationship between police officers' race, education level, and job performance. Journal of Police and Criminal Psychology, 18(1), 45-56.

Kappeler, V. E., Sapp, A. D., \& Carter, D. L. (1992). Police officer higher education, citizen complaints, and departmental rule violations. American Journal of Police, 11(2), 37-54.

Lersch, K. M., \& Kunzman, L. L. (2001). Misconduct allegations and higher education in a southern sheriff's department. American Journal of Criminal Justice, 25(2), 161-172.

Manis, J., Archbold, C. A., \& Hassell, K. D. (2008). Exploring the impact of police officer education level on allegations of police misconduct. International Journal of Police Science \& Management, 10(4), 509-523.

Martin, S. E. (1979). Policewomen and policewomen: Occupational role dilemmas and choices of female officers. Journal of Police Science and Administration, 7(3), 314-323.

National Planning Association. (1978). A nationwide survey of law enforcement: Criminal justice personnel needs and resources. Washington, DC: United States Government Printing Office.

National Research Council. (2004). Fairness and effectiveness in policing: The evidence. Washington, DC: National Academies Press. 
Oliver, W. M. (2017). August Vollmer: The father of American policing. Durham, NC: Carolina Academic Press, LLC.

Olson, E. A., Rosso, I. M., Demers, L. A., Divatia, S., \& Killgore, W. D. (2016). Sex differences in psychological factors associated with social discounting. Journal of Behavioral Decision Making, 29(1), 60-66.

Osborne, R. E. (2014). Observations on police cynicism: Some preliminary findings. North American Journal of Psychology, 16(3), 607-628.

Paoline, E. A. (2001). Rethinking police culture: Officers' occupational attitudes. New York: LFB Scholarly Publishing.

Paoline, E. A., Myers, S. M., \& Worden, R. E. (2000). Police culture, individualism, and community policing: Evidence from two police departments. Justice Quarterly, 17(3), $575-605$.

Paoline, E. A., \& Terrill, W. (2005). The impact of police culture on traffic stop searches: An analysis of attitudes and behavior. Policing: An International Journal of Police Strategies \& Management, 28(3), 455-472.

Paoline, E. A., \& Terrill, W. (2007). Police education, experience, and the use of force. Criminal Justice and Behavior, 34(2), 179-196.

Paoline, E. A., Terrill, W., \& Rossler, M. T. (2015). Higher education, college degree major, and police occupational attitudes. Journal of Criminal Justice Education, 26(1), 49-73.

Pelfrey, W. V. (2004). The inchoate nature of community policing: Differences between community policing and traditional police officers. Justice Quarterly, 21(3), 579-601.

Petrocelli, M., Piquero, A. R., \& Smith, M. R. (2003). Conflict theory and racial profiling: An empirical analysis of police traffic stop data. Journal of Criminal Justice, 31(1), 1-11.

President's Commission on Law Enforcement and the Administration of Justice. (1967). The challenge of crime in a free society. Washington, DC: U.S. Government Printing Office.

President's Task Force on 21st Century Policing. (2015). Final report of the President's Task Force on 21st Century Policing. Washington, DC: Office of Community Oriented Policing Services.

Reaves, B. (2015). Local police departments, 2013. Washington, DC: U.S. Department of Justice.

Ren, L., Cao, L., Lovrich, N., \& Gaffney, M. (2005). Linking confidence in the police with the performance of the police: Community policing can make a difference. Journal of Criminal Justice, 33(1), 55-66. 


\section{ARE COLLEGE-EDUCATED OFFICERS DIFFERENT?}

Roberg, R., \& Kuykendall, J. (1997). Police management. Roxbury, MA: Roxbury Publishing.

Rojek, J., \& Decker, S. H. (2009). Examining racial disparity in the police discipline process. Police Quarterly, 12(4), 388-407.

Rojek, J., Rosenfeld, R., \& Decker, S. (2012). Policing race: The racial stratification of searches in police traffic stops. Criminology, 50(4), 993-1024.

Rudas, T. (1998). Odds ratios in the analysis of contingency tables. Thousand Oaks, CA: Sage.

Rueckert, L., \& Naybar, N. (2008). Gender differences in empathy: The role of the right hemisphere. Brain and Cognition, 67(2), 162-167.

Rydberg, J., \& Terrill, W. (2010). The effect of higher education on police behavior. Police Quarterly, 13(1), 92-120.

Schafer, J. A., Carter, D. L., \& Katz-Bannister, A. (2004). Studying traffic stop encounters. Journal of Criminal Justice, 32(2), 159-170.

Schafer, J. A., Carter, D. L., Katz-Bannister, A. J., \& Wells, W. M. (2006). Decision making in traffic stop encounters: A multivariate analysis of police behavior. Police Quarterly, 9(2), 184-209.

Seklecki, R., \& Paynich, R. (2007). A national survey of female police officers: An overview of findings. Police Practice and Research, 8(1), 17-30.

Shelley, T. O. C., Morabito, M. S., \& Tobin-Gurley, J. (2011). Gendered institutions and gender roles: Understanding the experiences of women in policing. Criminal Justice Studies, 24(4), 351-367.

Sherman, L. W., \& Blumberg, M. (1981). Higher education and police use of deadly force. Journal of Criminal Justice, 9(4), 317-331.

Sherwood, C. W. (2000). Job design, community policing, and higher education: A tale of two cities. Police Quarterly, 3(2), 191-212.

Smith, D. A., \& Klein, J. R. (1983). Police agency characteristics and arrest decisions. In G. P. Whitaker \& C. D. Phillips (Eds.), Evaluating performance of criminal justice agencies (pp. 63-98). Beverley Hills: Sage.

Smith, B. W., Novak, K. J., Frank, J., \& Lowenkamp, C. (2005). Explaining police officer discretionary activity. Criminal Justice Review, 30(3), 325-346.

Stroshine, M. S., \& Brandl, S. G. (2011). Race, gender, and tokenism in policing: An empirical elaboration. Police Quarterly, 14(4), 344-365. 


\section{ARE COLLEGE-EDUCATED OFFICERS DIFFERENT?}

St. Louis Metropolitan Police Department. (2014). Annual report to the community: 2013. St. Louis, MO: St. Louis Metropolitan Police Department.

Sun, I. Y. (2003). Police officers' attitudes toward their role and work: A comparison of black and white officers. American Journal of Criminal Justice, 28(1), 89-108.

Telep, C. W. (2011). The impact of higher education on police officer attitudes toward abuse of authority. Journal of Criminal Justice Education, 22(3), 392-419.

Terrill, W., \& Mastrofski, S. D. (2002). Situational and officer-based determinants of police coercion. Justice Quarterly, 19(2), 215-248.

Texeira, M. T. (2002). "Who protects and serves me?": A case study of sexual harassment of African American women in one US law enforcement agency. Gender \& Society, 16(4), 524-545.

The Economist. (2017). Police departments struggle to recruit enough officers. Retrieved from https://www.economist.com/united-states/2017/01/05/police-departments-struggle-torecruit-enough-officers/.

Tillyer, R., Klahm IV, C. F., \& Engel, R. S. (2012). The discretion to search: A multilevel examination of driver demographics and officer characteristics. Journal of Contemporary Criminal Justice, 28(2), 184-205.

Truxillo, D. M., Bennett, S. R., \& Collins, M. L. (1998). College education and police job performance: A ten-year study. Public Personnel Management, 27(2), 269-280.

U. S. Bureau of the Census. (2010). Resident population data. Retrieved from https://www.census.gov/2010census/data/.

White, M. D. (2008). Identifying good cops early: Predicting recruit performance in the academy. Police Quarterly, 11(1), 27-49.

Worden, R. E. (1989). Situational and attitudinal explanations of police behavior: A theoretical reappraisal and empirical assessment. Law and Society Review, 23(4), 667-711.

Worden, R. E. (1990). A badge and a baccalaureate: Policies, hypotheses, and further evidence. Justice Quarterly, 7(3), 565-592.

Yoder, J. D., Aniakudo, P., \& Berendsen, L. (1996). Looking beyond gender: The effects of racial differences on tokenism perceptions of women. Sex Roles, 35(7-8), 389-400. 
ARE COLLEGE-EDUCATED OFFICERS DIFFERENT?

Table 1. Descriptive Statistics for Officer and Traffic Stop Variables

\begin{tabular}{|c|c|c|c|c|c|}
\hline & Mean & $\mathrm{SD}$ & Min & Max & $\mathrm{N}$ \\
\hline \multicolumn{6}{|l|}{ Officers } \\
\hline College & .293 & .456 & 0 & 1 & 842 \\
\hline Male & .855 & .352 & 0 & 1 & 842 \\
\hline Under 30 & .146 & .353 & 0 & 1 & 842 \\
\hline $30-49$ & .728 & .445 & 0 & 1 & 842 \\
\hline 50 and over & .126 & .332 & 0 & 1 & 842 \\
\hline Black & .340 & .474 & 0 & 1 & 842 \\
\hline White & .628 & .484 & 0 & 1 & 842 \\
\hline Other ethnic & .032 & .176 & 0 & 1 & 842 \\
\hline Traffic & .037 & .188 & 0 & 1 & 842 \\
\hline District & .710 & .454 & 0 & 1 & 842 \\
\hline Housing & .038 & .191 & 0 & 1 & 842 \\
\hline Anti-Crime & .087 & .282 & 0 & 1 & 842 \\
\hline Other duty & .128 & .335 & 0 & 1 & 842 \\
\hline Traffic stops & 75.4 & 147.8 & 1 & 1786 & 842 \\
\hline \multicolumn{6}{|l|}{ Traffic Stops } \\
\hline Officer college & .237 & .425 & 0 & 1 & 63451 \\
\hline Officer male & .873 & .333 & 0 & 1 & 63451 \\
\hline Officer under 30 & .183 & .387 & 0 & 1 & 63451 \\
\hline Officer 30 - 49 & .660 & .474 & 0 & 1 & 63451 \\
\hline Officer over 49 & .157 & .364 & 0 & 1 & 63451 \\
\hline Officer black & .371 & .483 & 0 & 1 & 63451 \\
\hline Officer white & .589 & .492 & 0 & 1 & 63451 \\
\hline Officer other ethnic & .040 & .197 & 0 & 1 & 63451 \\
\hline Officer traffic & .232 & .422 & 0 & 1 & 63451 \\
\hline Officer district & .594 & .491 & 0 & 1 & 63451 \\
\hline Officer housing & .036 & .187 & 0 & 1 & 63451 \\
\hline Officer anti-crime & .047 & .211 & 0 & 1 & 63451 \\
\hline Officer other duty & .091 & .287 & 0 & 1 & 63451 \\
\hline Driver male & .705 & .456 & 0 & 1 & 63448 \\
\hline Driver under 30 & .479 & .500 & 0 & 1 & 63451 \\
\hline Driver black & .710 & .454 & 0 & 1 & 63451 \\
\hline Driver white & .267 & .442 & 0 & 1 & 63451 \\
\hline Driver Hispanic & .009 & .095 & 0 & 1 & 63451 \\
\hline Driver Asian & .008 & .090 & 0 & 1 & 63451 \\
\hline Driver resident & .518 & .500 & 0 & 1 & 63448 \\
\hline Stop night & .190 & .392 & 0 & 1 & 63451 \\
\hline Stop evening & .295 & .456 & 0 & 1 & 63451 \\
\hline Stop day & .516 & .500 & 0 & 1 & 63451 \\
\hline
\end{tabular}


ARE COLLEGE-EDUCATED OFFICERS DIFFERENT?

Table 2. Educational Attainment by Officer Sex, Age, Race, and Duty Assignment $(\mathrm{N}=842)^{\mathrm{a}}$

\begin{tabular}{lccc}
\hline & \% College & \% Non-College & $p$ \\
\hline Officer male & 28.6 & 71.4 & \\
Officer female & 33.6 & 66.4 & .262 \\
& & & \\
Officer under 30 & 28.5 & 71.5 & \\
Officer 30 - 49 & 30.5 & 69.5 & \\
Officer over 49 & 23.6 & 76.4 & .343 \\
& & & \\
Officer black & 17.5 & 82.5 & \\
Officer white & 35.2 & 64.8 & \\
Officer other ethnic & 40.7 & 59.3 & .000 \\
& & & \\
Officer traffic & 9.7 & 90.3 & \\
Officer district & 30.6 & 69.4 & \\
Officer housing & 34.4 & 65.6 & \\
Officer anti-crime & 37.0 & 63.0 & \\
Officer other duty & 21.3 & 78.7 & .017 \\
& & & \\
\end{tabular}

${ }^{a}$ Differences evaluated by chi-square.

Table 3. Number of Traffics Stops and Characteristics of Drivers by Officer Educational Attainment $(\mathrm{N}=842)^{\mathrm{a}}$

\begin{tabular}{lccc}
\hline & College & Non-College & $p$ \\
\hline Mean traffic stops & 60.8 & 81.4 & .066 \\
\% driver male & & & \\
\% driver under 30 & 75.6 & 74.8 & .529 \\
\% driver black & 53.0 & 53.4 & .841 \\
\% driver white & 74.3 & 73.2 & .574 \\
\% driver Hispanic & 23.2 & 24.1 & .591 \\
\% driver Asian & 1.2 & 1.2 & .992 \\
& .5 & .6 & .216 \\
\hline
\end{tabular}

${ }^{\mathrm{a}}$ Differences evaluated by F-test. 


\section{ARE COLLEGE-EDUCATED OFFICERS DIFFERENT?}

Table 4. Discretionary Stops by Officer, Driver, and Stop Characteristics (No. of obs. $=63,448)^{\mathrm{a}}$

\begin{tabular}{|c|c|c|c|c|c|c|}
\hline & \multicolumn{3}{|c|}{ Non-moving Violation } & \multicolumn{3}{|c|}{ Non-speeding Violation } \\
\hline & (a) & (b) & (c) & (a) & (b) & (c) \\
\hline \multicolumn{7}{|l|}{ Officer } \\
\hline \multirow[t]{3}{*}{ College } & $1.200^{*}$ & $1.625^{*}$ & 1.192 & $1.503 * *$ & 1.897 & $1.431 *$ \\
\hline & $(.049)$ & $(.028)$ & $(.064)$ & $(.007)$ & $(.059)$ & $(.037)$ \\
\hline & [1.001-1.438] & {$[1.055-2.503]$} & [.990-1.436] & [1.116-2.024] & {$[.977-3.686]$} & [1.023-2.004] \\
\hline \multirow[t]{3}{*}{ Male } & 1.087 & 1.227 & 1.086 & 1.160 & 1.271 & 1.156 \\
\hline & $(.490)$ & $(.189)$ & $(.492)$ & $(.421)$ & $(.311)$ & $(.435)$ \\
\hline & {$[.858-1.376]$} & {$[.904-1.664]$} & {$[.858-1.374]$} & {$[.808-1.667]$} & {$[.799-2.021]$} & [.804-1.662] \\
\hline \multirow[t]{3}{*}{ Black } & $.696^{* *}$ & $.701 * *$ & $.692 * *$ & $1.723 * *$ & $1.733 * *$ & $1.652 * *$ \\
\hline & $(.000)$ & $(.000)$ & $(.001)$ & $(.000)$ & $(.000)$ & $(.003)$ \\
\hline & {$[.573-.844]$} & {$[.577-.850]$} & {$[.560-.854]$} & {$[1.285-2.311]$} & [1.291-2.328] & [1.190-2.294] \\
\hline \multirow[t]{3}{*}{ College x male } & --- & .699 & --- & --- & .759 & --- \\
\hline & --- & $(.135)$ & --- & --- & $(.459)$ & --- \\
\hline & --- & {$[.437-1.118]$} & --- & --- & {$[.366-1.575]$} & --- \\
\hline \multirow[t]{3}{*}{ College $\mathrm{x}$ black } & --- & --- & 1.026 & --- & --- & 1.253 \\
\hline & --- & --- & $(.919)$ & --- & --- & $(.548)$ \\
\hline & --- & --- & {$[.623-1.691]$} & --- & --- & {$[.601-2.611]$} \\
\hline \multirow[t]{3}{*}{ Under 30} & $2.212 * *$ & $2.220 * *$ & $2.212 * *$ & $3.253 * *$ & $3.251^{* *}$ & $3.252 * *$ \\
\hline & $(.000)$ & $(.000)$ & $(.000)$ & $(.000)$ & $(.000)$ & $(.000)$ \\
\hline & [1.474-3.319] & [1.481-3.327] & [1.475-3.319] & {$[1.828-5.786]$} & {$[1.828-5.784]$} & {$[1.827-5.786]$} \\
\hline \multirow[t]{3}{*}{$30-49$} & $1.878 * *$ & $1.885^{* *}$ & $1.878 * *$ & $2.560 * *$ & $2.561 * *$ & $2.558^{* *}$ \\
\hline & $(.001)$ & $(.001)$ & $(.001)$ & $(.000)$ & $(.000)$ & $(.000)$ \\
\hline & [1.284-2.744] & {$[1.291-2.752]$} & {$[1.285-2.744]$} & {$[1.559-4.205]$} & {$[1.560-4.205]$} & [1.556-4.203] \\
\hline \multirow[t]{3}{*}{ Other ethnic } & .773 & .783 & .773 & .566 & .572 & .567 \\
\hline & $(.225)$ & $(.252)$ & $(.225)$ & $(.121)$ & $(.130)$ & $(.122)$ \\
\hline & [.510-1.172] & {$[.515-1.190]$} & [.510-1.172] & {$[.275-1.162]$} & {$[.278-1.178]$} & [.276-1.164] \\
\hline \multirow[t]{3}{*}{ Traffic } & $.176^{* *}$ & $.176^{* *}$ & $.177 * *$ & $.080 * *$ & $.080 * *$ & $.080 * *$ \\
\hline & $(.000)$ & $(.000)$ & $(.000)$ & $(.000)$ & $(.000)$ & $(.000)$ \\
\hline & [.089-.348] & [.089-.346] & {$[.090-.348]$} & {$[.035-.183]$} & [.035-.182] & [.035-.184] \\
\hline \multirow[t]{3}{*}{ District } & .937 & .935 & .937 & 1.142 & 1.138 & 1.147 \\
\hline & $(.592)$ & $(.583)$ & $(.595)$ & $(.582)$ & $(.590)$ & $(.568)$ \\
\hline & {$[.737-1.190]$} & [.736-1.189] & [.737-1.191] & [.712-1.829] & [.710-1.824] & [.716-1.838] \\
\hline \multirow[t]{3}{*}{ Housing } & 1.256 & 1.253 & 1.259 & $2.361^{*}$ & $2.362^{*}$ & $2.418^{*}$ \\
\hline & $(.315)$ & $(.319)$ & $(.310)$ & $(.020)$ & $(.020)$ & $(.017)$ \\
\hline & [.805-1.959] & {$[.805-1.950]$} & [.807-1.965] & [1.146-4.865] & [1.147-4.864] & [1.168-5.008] \\
\hline \multirow[t]{3}{*}{ Anti-crime } & $.692 *$ & $.687 *$ & $.692 *$ & $.504 *$ & $.501^{*}$ & $.507 *$ \\
\hline & $(.027)$ & $(.024)$ & $(.027)$ & $(.017)$ & $(.016)$ & $(.018)$ \\
\hline & [.499-.958] & [.496-.952] & {$[.500-.958]$} & [.288-.883] & [.286-.878] & [.290-.889] \\
\hline \multicolumn{7}{|l|}{ Driver } \\
\hline \multirow[t]{3}{*}{ Male } & .999 & .999 & .999 & .996 & .996 & .996 \\
\hline & $(.984)$ & $(.985)$ & $(.984)$ & $(.900)$ & $(.900)$ & $(.900)$ \\
\hline & {$[.950-1.051]$} & {$[.950-1.051]$} & {$[.950-1.051]$} & {$[.928-1.068]$} & {$[.928-1.068]$} & [.928-1.067] \\
\hline \multirow[t]{3}{*}{ Under 30} & $.952 *$ & $.952 *$ & $.952 *$ & $.832 * *$ & $.832 * *$ & $.832 * *$ \\
\hline & $(.041)$ & $(.041)$ & $(.041)$ & $(.000)$ & $(.000)$ & $(.000)$ \\
\hline & [.909-.998] & [.909-.998] & [.909-.998] & [.766-.905] & [.766-.905] & [.766-.905] \\
\hline \multirow[t]{3}{*}{ Black } & $1.666^{* *}$ & $1.665 * *$ & $1.666 * *$ & $1.281 *$ & $1.281 *$ & $1.281 *$ \\
\hline & $(.000)$ & $(.000)$ & $(.000)$ & $(.018)$ & $(.018)$ & $(.018)$ \\
\hline & [1.530-1.813] & [1.529-1.813] & {$[1.530-1.813]$} & [1.043-1.574] & {$[1.042-1.574]$} & {$[1.043-1.574]$} \\
\hline Hispanic & 1.219 & 1.219 & 1.219 & 1.412 & 1.412 & 1.411 \\
\hline & $(.055)$ & $(.055)$ & $(.055)$ & $(.105)$ & $(.106)$ & $(.106)$ \\
\hline & [.996-1.492] & [.996-1.491] & [.996-1.492] & [.930-2.144] & [.930-2.143] & [.930-2.143] \\
\hline
\end{tabular}




\section{ARE COLLEGE-EDUCATED OFFICERS DIFFERENT?}

Table 4. Discretionary Stops, continued ${ }^{\mathrm{a}}$

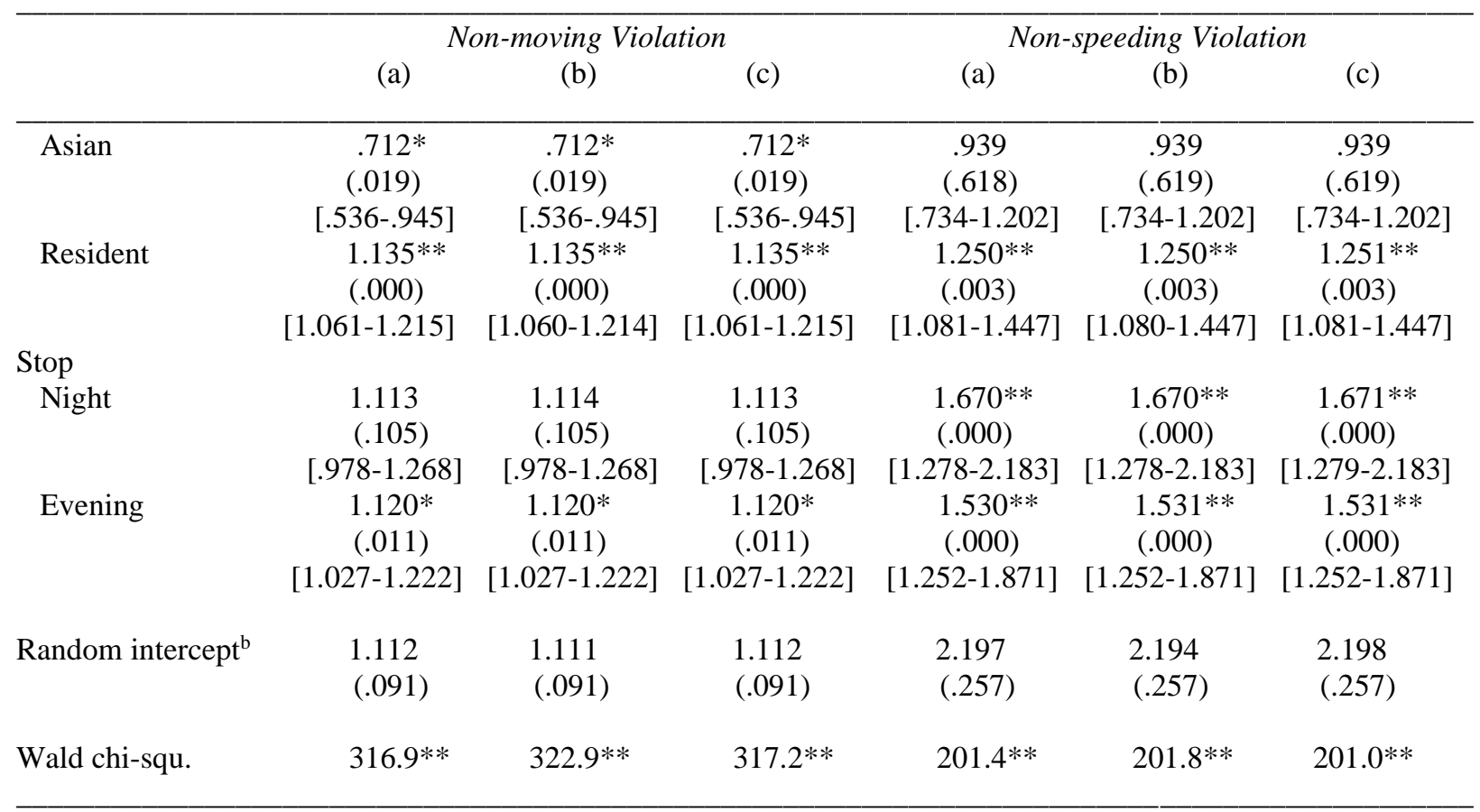

${ }^{a}$ Odds ratios from mixed effects logistic regressions. P-values, in parentheses, based on clustered robust standard errors; $95 \%$ confidence intervals in brackets. No. of groups (officers) $=841$.

${ }^{\mathrm{b}}$ Robust standard error in parentheses.

$* * p<.01 * p<.05$ 


\section{ARE COLLEGE-EDUCATED OFFICERS DIFFERENT?}

Table 5. Consent Searches and Contraband Discovered by Officer, Driver, and Stop Characteristics ${ }^{\mathrm{a}}$

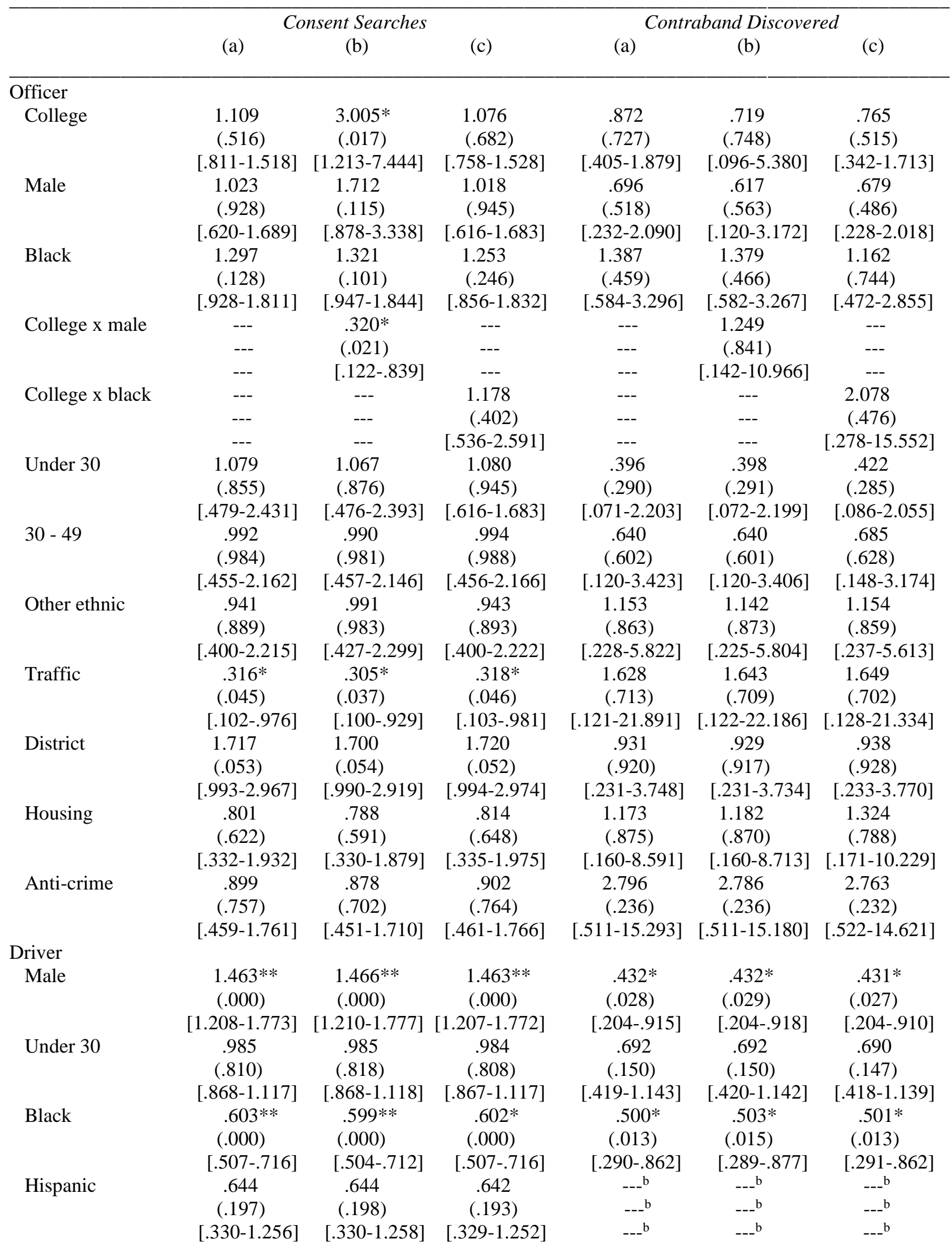




\section{ARE COLLEGE-EDUCATED OFFICERS DIFFERENT?}

Table 5. Consent Searches and Contraband Discovered, continued ${ }^{\mathrm{a}}$

\begin{tabular}{|c|c|c|c|c|c|c|}
\hline & \multicolumn{3}{|c|}{ Consent Searches } & \multicolumn{3}{|c|}{ Contraband Discovered } \\
\hline & (a) & (b) & (c) & (a) & (b) & (c) \\
\hline \multirow[t]{3}{*}{ Asian } & .510 & .513 & .511 & $---^{b}$ & $---b$ & $---^{b}$ \\
\hline & $(.324)$ & $(.334)$ & $(.326)$ & $---{ }^{b}$ & $---{ }^{b}$ & $---^{b}$ \\
\hline & {$[.134-1.945]$} & {$[.133-1.984]$} & {$[.134-1.952]$} & $---b$ & $---{ }^{b}$ & $---{ }^{b}$ \\
\hline \multirow[t]{3}{*}{ Resident } & .857 & .855 & .857 & 1.095 & 1.093 & 1.094 \\
\hline & $(.093)$ & $(.087)$ & $(.093)$ & $(.716)$ & $(.721)$ & $(.719)$ \\
\hline & {$[.716-1.026]$} & {$[.714-1.023]$} & {$[.716-1.026]$} & {$[.671-1.787]$} & {$[.672-1.778]$} & {$[.671-1.783]$} \\
\hline \multicolumn{7}{|l|}{ Stop } \\
\hline \multirow[t]{3}{*}{ Night } & .846 & .847 & .847 & .607 & .606 & .612 \\
\hline & $(.140)$ & $(.142)$ & $(.143)$ & $(.254)$ & $(.254)$ & $(.257)$ \\
\hline & {$[.677-1.057]$} & {$[.678-1.057]$} & {$[.678-1.058]$} & {$[.257-1.432]$} & {$[.256-1.432]$} & {$[.262-1.430]$} \\
\hline \multirow[t]{3}{*}{ Evening } & .974 & .974 & .974 & .776 & .776 & .778 \\
\hline & $(.697)$ & $(.696)$ & $(.699)$ & $(.376)$ & $(.376)$ & $(.378)$ \\
\hline & [.854-1.112] & {$[.853-1.112]$} & {$[.854-1.112]$} & {$[.443-1.360]$} & {$[.443-1.360]$} & {$[.445-1.360]$} \\
\hline \multirow[t]{2}{*}{ Random intercept ${ }^{\mathrm{c}}$} & 1.828 & 1.792 & 1.832 & 2.384 & 2.360 & 2.254 \\
\hline & $(.190)$ & $(.188)$ & $(.191)$ & $(1.237)$ & $(1.252)$ & (1.194) \\
\hline Wald chi-squ. & $102.2 * *$ & $110.3 * *$ & $102.7 * *$ & $28.5^{*}$ & $28.5^{*}$ & $28.8 *$ \\
\hline \multicolumn{2}{|c|}{ No. of groups (officers) } & 609 & & & 405 & \\
\hline \multicolumn{2}{|c|}{ No. of obs. } & 7560 & & & 2646 & \\
\hline
\end{tabular}

${ }^{\text {a }}$ Odds ratios from mixed effects logistic regressions. P-values, in parentheses, based on clustered robust standard errors; $95 \%$ confidence intervals in brackets.

${ }^{\mathrm{b}}$ No observations.

${ }^{\mathrm{c}}$ Robust standard error in parentheses.

$* * p<.01 * p<.05$ 


\section{ARE COLLEGE-EDUCATED OFFICERS DIFFERENT?}

Table 6. Arrests by Officer, Driver, and Stop Characteristics $(\text { No. of obs. }=53,856)^{\mathrm{a}}$

\begin{tabular}{|c|c|c|c|}
\hline & (a) & $\begin{array}{l}\text { Arrests } \\
\text { (b) }\end{array}$ & (c) \\
\hline \multicolumn{4}{|l|}{ Officer } \\
\hline \multirow[t]{2}{*}{ College } & $\begin{array}{c}2.007 * \\
(.041)\end{array}$ & $\begin{array}{l}1.463 \\
(.650)\end{array}$ & $\begin{array}{l}1.995 \\
(.086)\end{array}$ \\
\hline & [1.029-3.914] & {$[.283-7.571]$} & [.907-4.390] \\
\hline \multirow[t]{2}{*}{ Male } & $\begin{array}{l}.615 \\
(.266)\end{array}$ & $\begin{array}{l}.529 \\
(.258)\end{array}$ & $\begin{array}{l}.614 \\
(.266)\end{array}$ \\
\hline & {$[.260-1.450]$} & [.176-1.592] & {$[.260-1.450]$} \\
\hline \multirow[t]{2}{*}{ Black } & $\begin{array}{l}1.159 \\
(.691)\end{array}$ & $\begin{array}{l}1.151 \\
(.704)\end{array}$ & $\begin{array}{l}1.152 \\
(.739)\end{array}$ \\
\hline & [.560-2.396] & {$[.557-2.380]$} & {$[.500-2.654]$} \\
\hline \multirow[t]{3}{*}{ College x male } & --- & 1.459 & --- \\
\hline & --- & $(.681)$ & --- \\
\hline & --- & {$[.242-8.804]$} & --- \\
\hline \multirow[t]{3}{*}{ College $\mathrm{x}$ black } & --- & --- & 1.021 \\
\hline & --- & --- & $(.979)$ \\
\hline & --- & --- & [.216-4.830] \\
\hline \multirow[t]{2}{*}{ Under 30} & $\begin{array}{l}.880 \\
(.842)\end{array}$ & $\begin{array}{c}.876 \\
(.835)\end{array}$ & $\begin{array}{l}.880 \\
(.841)\end{array}$ \\
\hline & {$[.251-3.087]$} & {$[.250-3.066]$} & {$[.251-3.083]$} \\
\hline \multirow[t]{2}{*}{$30-49$} & $\begin{array}{l}1.045 \\
(.937)\end{array}$ & $\begin{array}{l}1.034 \\
(.952)\end{array}$ & $\begin{array}{l}1.045 \\
(.937)\end{array}$ \\
\hline & {$[.355-3.078]$} & {$[.350-3.054]$} & [.355-3.073] \\
\hline \multirow[t]{3}{*}{ Other ethnic } & 2.287 & 2.262 & 2.285 \\
\hline & $(.188)$ & (.196) & (.189) \\
\hline & [.667-7.842] & {$[.657-7.788]$} & [.667-7.834] \\
\hline \multirow[t]{2}{*}{ Traffic } & $\begin{array}{l}.660 \\
(.500)\end{array}$ & $\begin{array}{l}.664 \\
(.503)\end{array}$ & $\begin{array}{c}.661 \\
(.505)\end{array}$ \\
\hline & [.198-2.207] & [.201-2.197] & [.195-2.236] \\
\hline \multirow[t]{2}{*}{ District } & $\begin{array}{l}.418 \\
(.088)\end{array}$ & $\begin{array}{l}.422 \\
(.089)\end{array}$ & $\begin{array}{l}.418 \\
(.089)\end{array}$ \\
\hline & [.153-1.139] & {$[.156-1.140]$} & [.152-1.144] \\
\hline \multirow[t]{2}{*}{ Housing } & $\begin{array}{l}.622 \\
(.560)\end{array}$ & $\begin{array}{l}.624 \\
(.561)\end{array}$ & $\begin{array}{l}.623 \\
(.567)\end{array}$ \\
\hline & [.126-3.072] & {$[.127-3.064]$} & [.123-3.149] \\
\hline \multirow[t]{3}{*}{ Anti-crime } & 1.251 & 1.269 & 1.252 \\
\hline & $(.772)$ & $(.758)$ & $(.773)$ \\
\hline & {$[.274-5.710]$} & {$[.278-5.793]$} & [.273-5.737] \\
\hline \multicolumn{4}{|l|}{ Driver } \\
\hline \multirow[t]{3}{*}{ Male } & $2.165^{* *}$ & $2.164 * *$ & $2.165^{* *}$ \\
\hline & $(.000)$ & $(.000)$ & $(.000)$ \\
\hline & [1.468-3.193] & [1.467-3.192] & [1.469-3.191] \\
\hline \multirow[t]{3}{*}{ Under 30} & 1.126 & 1.126 & 1.126 \\
\hline & $(.514)$ & $(.514)$ & $(.514)$ \\
\hline & [.789-1.605] & [.789-1.605] & [.789-1.605] \\
\hline \multirow[t]{3}{*}{ Black } & $.418^{* *}$ & $.420^{* *}$ & $.418 * *$ \\
\hline & $(.000)$ & $(.000)$ & $(.000)$ \\
\hline & [.264-.663] & [.265-.665] & [.264-.663] \\
\hline
\end{tabular}




\section{ARE COLLEGE-EDUCATED OFFICERS DIFFERENT?}

Table 6. Arrests, cont.

$(\text { No. of obs. }=53,856)^{\mathrm{a}}$

Arrests

(a) (b)

(c)

\begin{tabular}{|c|c|c|c|}
\hline \multirow[t]{3}{*}{ Hispanic } & $--{ }^{b}$ & $-{ }_{--} b$ & $-{ }_{--}^{b}$ \\
\hline & $---b$ & $---b$ & $--^{b}$ \\
\hline & --- b & $---{ }^{b}$ & ---- b \\
\hline \multirow[t]{3}{*}{ Asian } & $---b$ & $---{ }^{b}$ & $---b$ \\
\hline & $---{ }^{b}$ & $---^{b}$ & $---{ }^{b}$ \\
\hline & $---{ }^{b}$ & $---{ }^{b}$ & $---{ }^{b}$ \\
\hline \multirow[t]{3}{*}{ Resident } & 1.081 & 1.081 & 1.081 \\
\hline & $(.782)$ & $(.781)$ & $(.781)$ \\
\hline & [.624-1.873] & [.624-1.871] & [.624-1.873] \\
\hline \multicolumn{4}{|l|}{ Stop } \\
\hline \multirow[t]{3}{*}{ Night } & 1.838 & 1.835 & 1.838 \\
\hline & $(.124)$ & $(.125)$ & $(.124)$ \\
\hline & [.847-3.988] & {$[.845-3.986]$} & [.847-3.988] \\
\hline \multirow[t]{3}{*}{ Evening } & $2.072 * *$ & $2.071 * *$ & $2.072 * *$ \\
\hline & $(.006)$ & $(.007)$ & $(.006)$ \\
\hline & [1.226-3.502] & [1.224-3.502] & [1.226-3.502] \\
\hline \multirow[t]{2}{*}{ Random intercept ${ }^{\mathrm{c}}$} & 3.914 & 3.895 & 3.914 \\
\hline & (1.106) & (1.102) & (1.106) \\
\hline Wald chi-squ. & $66.1 * *$ & $66.7 * *$ & $66.1^{* *}$ \\
\hline
\end{tabular}

${ }^{a}$ Odds ratios from mixed effects logistic regressions. P-values, in parentheses, based on clustered robust standard errors; $95 \%$ confidence intervals in brackets.

Number of groups (officers) $=804$. Stops of drivers wanted on warrant and stops resulting in a search omitted.

${ }^{\mathrm{b}}$ No observations.

${ }^{\mathrm{c}}$ Robust standard error in parentheses.

$* * p<.01 * p<.05$ 
ARE COLLEGE-EDUCATED OFFICERS DIFFERENT?

Figure 1. Effect of Higher Education on Consent Searches by Officer Sex $(N=7,560)$

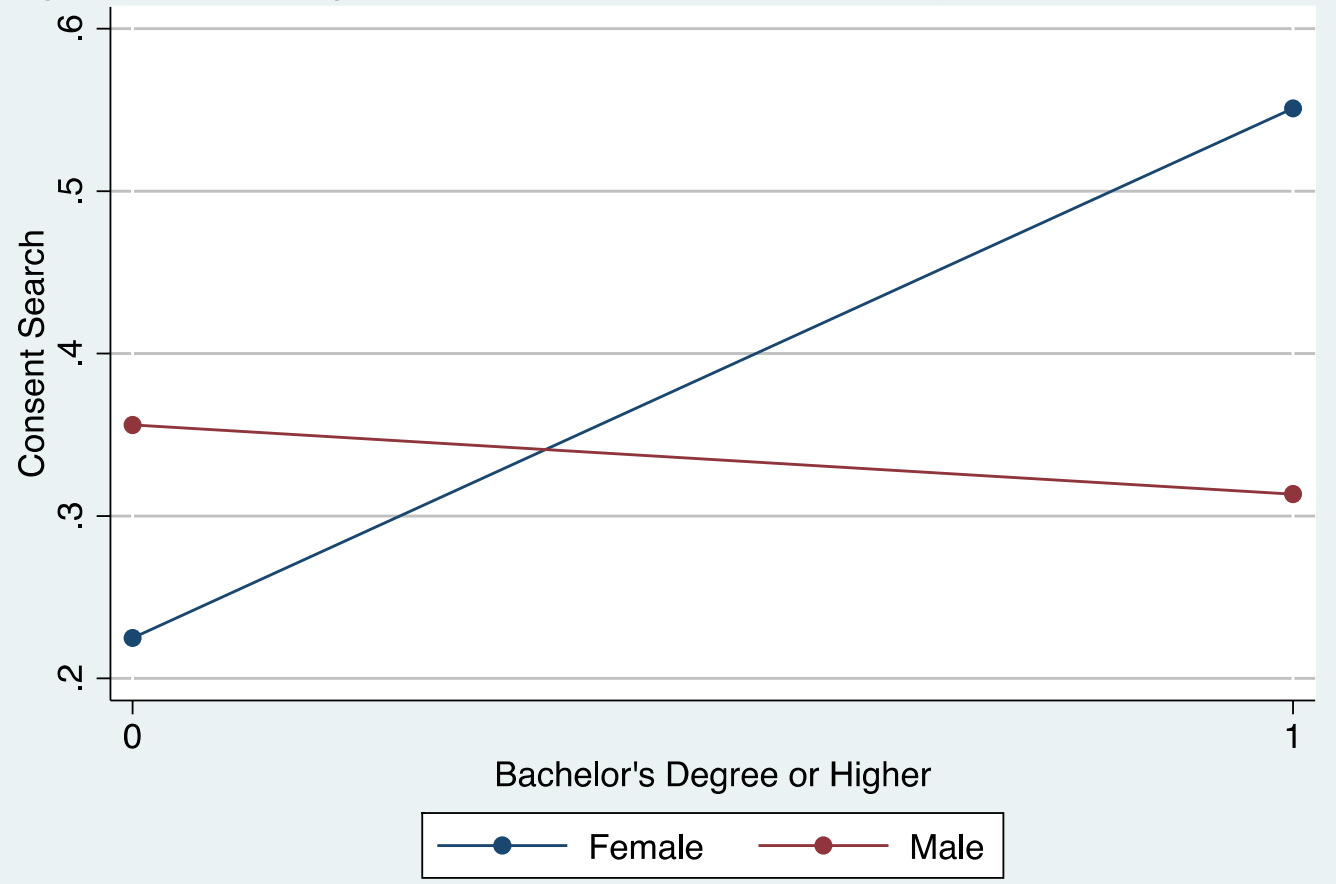

